\title{
KEARIFAN BUDAYA MASYARAKAT TRADISIONAL DALAM PENGELOLAAN LINGKUNGAN HIDUP
}

\author{
(Kasus : Penduduk Desa Tubbi-Polmas) \\ Oleh : M. Yamin Sani*
}

\section{PENDAHULUAN}

Menurut kualitas lingkungan, khususnya lingkungan fisik dewasa ini, semakin disadari sebegai masalah ekologis yang berdimansi global. Masalah ekologis tersebut demikian memprihatinkan berhubungan karena dampaknya dapat membahayakan kelangsungan hiidup manusia.

Dari sumber tersebut diketahui, bahwa penyebab timbulnya fenomena tersebut, tidak lain dari pada perilaku manusia penghuni bumi itu sendiri. Makin luasnya areal perkebunan, penebangan kayu secara komersial oleh pemegang $\mathrm{HPH}$, perombakan hutan untuk pemukiman akibat rnakin meningkatnya petumbuhan penduduk dan perambahan hutan, tewrmasuk dalam hal ini perladangan berpindah-pindah (shifting cultivation), disebut sebagi penyebab kerusakan hutan.

Khusus dalam hal perambahan hutan, dalam hal ini peladangan berpindah-pindah, masih menimbulkan polimik dikalangan ahli, terutama ahli antropologi. Beberapa hasil penelitian mereka menunjukkan, bahwa kerusakan hutan bukan disebabkan oleh peladang berpindah tradisional (lihat Vayda, 1981 ; Dove, 1983). Peladang berpindah tersebut melakukan kegiatan perladangan didasarkan atas aturan-aturan yang mereka warisi turun menurun (Vayda, 1981). Aturanaturan ini menjadikan mereka memiliki semacam kearifan ekologis (ecological wisdom) didalam melakukan pengelolaan hutan. Lagi pula, taraf sosial ekonomi peladang berpindah yang masih subsistem, menyebabkan hutan yang mereka kelola atau gunakan untuk nercocok tanam relatif terbatas.
Soemarwoto (1983) mengemukakan, peladangan berpindah merupakan adaptasi terbaik masyarakat yang tikat teknologinya rendah terhadap tingkat kesuburan tanah yartg rendah, Namun demikian, apabila perladangan berpindah itu terganggu yang memaksa daur perladangan menjadi pendek, maka kegiatan ini akan mengakibatkan timbulnya padang alang-alang.

Gejala kerusakan hutan akibat perladangan berpindah terjadi di Lng Segar Kalimantan Timur,akibat penerimaan informasi penduduk didaerah tersebut dalam bentuk penggunaan gergaji besi. Tujuannya adalah untuk memperluas tanah pertanian mereka mereka, disamping untuk mengkomersilkan kayu gergajian. Dan ini terjadi karena tingkat subsistensi dalam masyarakat permbah hutan sudah mulai goyah akibat pengaruh nilai uang. Dalam hal ini Vayda (1981) meyebutnya sebagai penolak kebijaksanaan (Wise rejector) yang terjadi pada peladang berpindah seperti itu.

Dari perspektif ilmu sosial, Khususnya para ahli antropologi, ekologi melihat aktifitas pemanfaatan sumber daya hutan sebagai salah satu sumber daya manusia untuk menyesuaikan diri terhadap lingkungan. Namun demikian, jika aktivitas perladangan dilakukan secara berlebihan sehingga melebihi daya dukung lingkungan, maka bukan tidak mungkin aktivitas perladangan tersebut akan menimbulkan kerusakan ekosistem hutan. Karena itu, pakar itu sendiri memberi penilaian berbeda terhadap permbah hutan, khususnya perladangan berpindah sebagai aktor pemelihara dan perusak lingkungan. Perbedaan ini terjadi sebagai akibat 
perbedaan disiplin ilmu dan sudut pendang tentang perladangan berpindah. Dalam bubungan ini menurut Vayda (1981) merupakan bukti adanya spektrum luas dari perilaku yang telah dimasukkan dalam kategori perladangan berpindah.

Artikel ini akan membahas sebuah kasus, bagaimana komunikasi yang tinggal di dalam dan sekitar hutan desa Tubbi Polmas memanfaatkan hutan, baik sebagai ladang perladangan maupun untuk tujuan lain yang didasarkan pada suatu kearifan budaya yang memungkinkan ekosistem hutan tidak bagitu terganggu.

\section{TAU BAQBUTTU DI DESA TUBBI}

Tau Baqbuttu adalah orang-orang yang menjadi penduduk dengan bermukim didalam dan sekitar kawasan nutan di desa Tubbi adalah orang-orang mandar, mereka berkomunikasi dalam bahasa Mandar dan menjadi pendukung kebudayaan mandar. Hanya saja dalam keseharian, Tau Baqbuttu nampak lebih bersahaja dibanding dengan orang Mandar pantai. Kebersahajaan tersebut nampak pada prinsip hidup mereka yang tidak kompetitif dan barusaha menghindari konflik serta kecenderungan untuk selalu menerima keadaan sebagaiman adanya.

Sebagai pendukung kebudayaan Madar gunung gunung, mereka memiliki Variasi kebudayanan yang agak berbeda dengan orang mandar pantai. Variasi kebudayaan tersebut terlihat pada perbedaan dialek bahasa (ragam lokal) dan beberapa bentuk tradisi berkenan dengan siklus kehidupan. Bahkan terdapat perbedaan intra budaya sesama Tau Paqbuttu itu sendiri. Didesa Tubbi terdapat paling tidak dua macam dialek : dialek "koo" dialek "Polebani". Dialek Koo digunakan oleh orang-orang yang menjadi penduduk asli desa Tubbi, sementara pemakai dialek polebani, banyak dipengaruhi oleh bahasa Mandar pantai, khususnya Balanipa. Namaun demikian, perbedaan antara danintra budaya, baik terhadap orang Mandar pantai dengan sesamamandar gunung, pada hakikatnya mereka sama-sama mendukung dan penganut agama islam yang baik dan tradisi budaya dalam komunitas mereka sama-sama memperoleh pengaruh agama Islam.

Tau Paqbuttu mempunyai metodologi sendiri untuk menelusuri asal usul mereka. Konsep Tau Manurung atau orang pertama yang manjadi raja dikawasan pegunungan, memberikan pengaruh demikian besar terhadap tatanan kehidupan komunitas dan identiras mereka sebagai orang gunung (Tau Paqbuttu) yang saat ini mendiami desa Tubbi.

Tubbi, sebuah desa pegunungan yang sebagian besar wilayahnya terletak pada ketinggian 700 meter diatas permukaan laut, adalah salah satu desa diantara sebelas desa yang termasuk dalam wilayah kecamatan Tuttallu, kabupaten Powelangi Mamasa, Jarak desa Tubbi ke Ibukota kecamatan, Pettosong, sebeuarnya hanya sekitar $48 \mathrm{~km}$, tetapi jarak tersebut ditempuh paling tidak 3,5 jam akibat prasarana jalan yang kurang memadai, telebih-lebih pada musim hujan.

Desa Tubbi membawahi 4 buah dusun, yaitu dusun Bunnu, Tubbi, Rettekallang dan Kamande. Dusun-dusun tersebut dihubungkan oleh jalan tanah berbatu yang tidak seberapa lebar. Masing-masing dusun membawahi 2 Rukun Kampung (RK) yang selanjutnya terbagi dalam beberapa Rukun Tetangga (RT).

Pada umumnya penduduk desa Tubbi adalah orang-orang yang dilahirkan dan dibesarkan dalam keluarga yang juga dilahirkan di dusun-dusun dalam wilayah desa Tubbi, atau paling tidak berasal dari desadesa sekitar yang sejak dahulu telah memiliki pertalian sejarah lokal bersama.

Orang-orang luar yang baru satu dua dekade terakhir berdomisili di desa Tubbi, juga orang-orang Mandar yang pada umumnya berasal dari desa-desa pantai di Polmas. Mereka ini berdomisili didesa Tobbi sebagai pedagang musiman atau penyewaan kuda 
KEARIFAN BUDAYA MASYARAKAT TRADISIONAL DALAM PENGELOLAAN LINGKUNGAN HIDUP

beban yang berfungsi sebagai saran transportasi (patteke).

Penduduk desa Tubbi berjumlah 3118 jiwa, terdiri atas laki-laki 1547 orang dan perempuan 1571 orang. Mereka ini terdiri atas $575 \mathrm{KK}$ yang terbesar pada empat dusun yang mereka dirikan pada tepi sungai Mapi, sebuah sungai terbesar yang membela kawasan hutan di desa Tubbi.

\section{PERLADANGAN : NAFAS KEHIDUPAN KOMUNITAS PENDUDUK DESA TUBBI}

Hutan sebagai kumunitas biotik dan abiotik merupakan sumberdaya yang demikian besar manfaatnya, terutama bagi penduduk yang bermukim di dalam dan sekitar kawasan hutan. Timbunan seresah pohon menjadikan lapisan tanah hutan menjadi subur, dan ini memberi peluang bagi penduduk lokal untk mengembangkan pola aktivitas perladangan. Sementara sumberdaya dalam bentuk kayu pohon, mereka manfaatkan sebagai bahan bakar dan bangunan rumah hunian. Selain itu, di hutan tumbuh jenis tumbuhan liar seperti sagu, gadung dan jamur pohon yang dimanfaatkan sebagai bahan pangan alternatif, manakala tanaman padi ladang mengalami gangguan musim yang meyebabkan tingkat produksi tidak cukup untuk dikonsumsikan oleh anggota komunitas. Dan yang tidak kurang pentingnya adalah ahsil hutan ikutan lainnya seperti rotan, damar, ijuk, madu dan beberapa jenis tanaman lainnya yang bernilai ekonomi, termasuk buah-buahan yang selain dapat dijadikan bahan baku industri rumah tangga, juga dapat dipasarkan secara langsung.

Jika kemudian timbul pertanyaan, mengapa penduduk dalam kawasan dan sekitar hutan tetap eksis, bahkan nampak demikian tentram menjalani hidup keseharian mereka ? jawaban rasional yang dapat diberikan, bahwa sumberdaya hutan menyediakan dan memenuhi kebutuhan mereka. Hampir semua bahan pangan yang diperlukan dapat diperoleh dengan cara memproduksi atau meramunya, karena banyak bahan pangan alternatif tumbuh secara liar di hutan-hutan. Sementara kebutuhan akan protein mereka penuhi dengan mengkomsumsi ikan-ikan sungai dan daging binatang dan binatang buruan yang mereka tangkap. Tetapi karena terbatasnya jumlah ikan dan binatang buruan yang mereka tangkap, menyebabkan ikan kering menjadi menu penting dalam konsumsi mereka.

Bagi penduduk dalam kawasan dan sekitar hutan, pola perladangan merupakan salah satu bentuk strategi adaptif terhadap ekosistem hutan yang telah berlangsung sejak dahulu kala, jauh sebelum cara bercocok tanam menetap ditemukan. Tradisi berladang masih tetap bertahan pada banyak komunitas di negara-negara sedang berkembang, termasuk Indonesia, karena sistem mata pencaharian ini mampu mengantarkan komunitas peladang pada tingkat produksi subsistensi, bahakn tidak jarang mereka mencapai surplus. Dalam kondisi seperti ini, komunitas peladang, tidak saja mampu untuk bertahan, tetapi mereka mampu untuk berkembang dari satu generasi ke generasi yang berikutnya. Mungkin karena alasan seperti itu, Netting (1977) menilai komunitas peladang berpindah tergolong makmur (the most affluent society).

Hasil penelitian penulis terhadap sebuah komunitas peladang berpindah di daerah daratan tinggi Polmas Sulawesi Selatan menunjukkan, bahwa dalam satu hektar ladang dapat menghasilkan lebih kurang 400450 ikat padi ladang yang pada setiap ikat berisi 3-4 liter beras setelah diproses. Ini berarti, dari jumlah 400-450 ikat padi ladang akan menghasilkan kira-kira 1500 liter beras. Jika dalam satu keluarga batih berjumlah 5 orang dengan konsumsi beras sebanyak 3 liter sehari, berarti dalam satu bulan akan menghasilkan sebanyak 90 liter atau sebanyak kira-kira 1100 liter setahun. Dengan jumlah konsumsi sebanyak itu, masih akan tersisa sebanyak 400 liter beras. 
KEARIFAN BUDAYA MASYARAKAT TRADISIONAL

DALAM PENGELOLAAN LINGKUNGAN HIDUP

Dengan tingkat produksi yang mencapai surplus ditambah penghasilan lain dari hasil hutan ikutan lainnya, anggota komunitas peladang mampu untuk memenuhi kebutuhan kalori yang mereka butuhkan untuk mengimbangi jumlah energi yang hilang akibat kerja keras di ladang. Dengan surplus tersebut, juga memungkin peladang untuk memenuhi kebutuhan akan pengadaan dana seremonial, dana pengganti dan perbaikan peralatan sebagai perangkat impretatif sosial yang mereka tidak dapat hindari sebagai akibat cara hidup komunitas yang masih patuh pada ikatan primordial.

Dalam pandangan peladang, pola aktivitas perladangan tidak sekedar memberinya peluang untuk sekedar hidup dengan prinsip mendahulukan selamat (Scott, 1983), tetapi dengan kegiatan tersebut memberi peluang bagi komunitas untuk mengembangkan jaringan sosial mikro, maupun jaringan sosial makro. Sebagai akibatnya, bahwa anggota komunitas akan terdorong untuk menciptakan dinamika perubahan sosial. Karenanya kita akan keliru, jika memahami komunitas peladang berpindah sebagai contoh komunitas statis. Spirit komunitas mendorong terjadinya interaksi intra dan antar kelompok, bahkan transaksi jual-beli dengan menggunakan uang tunai maupun sistem barter dengan pedagang luar merupakan pemandangan atau kejadian biasa pada musim panen.

Sebagai nafas kehidupan, peladang berpindah mengetahui betul, bagaimana mereka memperlakukan lahan perladangan sehingga dapat dimanfaatkan secara berkelanjutan. Karena itu, praktek perladangan bagi komunitas lokal bukan dilakukan tanpa pertimbangan rasional berdasarkan logika tradisional. Ahli antropologi ekologi menyebut logika tradisional tersebut sebagai kearifan ekologi (Ecological Wisdom). Sebagaimana dikemukakan oleh Dove (1988), bahwa pada umumnya masyarakat lokal asli yang tinggal di kawasan hutan, memiliki suatu bentuk kearifan yang sangat tinggi terhadap lingkungannya. Pandangan ini bahkan mengukuhkan komunitas peladang berpidah sebagai konservator akibat dari praktek perladangan yang ternyata memberi kesempatan bagi hutan untuk bergenerasi.

Praktek perladangan perladangan pada umumnya peladang tradisional, terikat pada suatu sistem norma perladangan yang menuntun mereka, bagaimana harus memilih dan membuka lahan perladangan di kawasan hutan, bagaimana harus menebas dan membakar hutan dan semak-semak, bagaimana harus menanam dan menjaga sampai pada menanam serta mengumpulkan dan menyimpan hasil ladang. Demikian pula, mereka mengetahui berapa lama harus menggunakan lahan perladangan dalam suatu hamparan kawasan hutan.

Komunitas peladang di daratan tinggi Polmas Sulawesi Selatan memiliki apa yang mereka sebut "Odiadaq Odibiasa" yang memuat norma perladangan, yang sekaligus menjadi mekanisme kontrol untuk tidak mengeksploitasi hutan secara sewenangwenang. Praktek perladangan seperti ini, ternyata mampu menjaga keseimbangan ekosistem. Dan sebagai akibatnya, tanah hutan di daerah tersebut tetap subur.

Dalam kurun waktu dua dekade terakhir, telah terjadi perubahan pola perladangan yang tidak hanya terikat pada tanaman semusim, tetapi juga terkonsentrasi pada tanaman perladangan (cash crop). Perubahan pola perladangan ini terjadi juga sebagai strategi adaptif dalam pendayagunaan lahan yang semakin terbatas sabagai akibat munculnya angkatan kerja baru dan diberlakukannya kebijaksanaan Tata Guna Hutan Kesepakatan (TGHK) yang menetapkan adanya batas-batas hutan lindung, yakni kawasan hutan yang dilarang oleh pemerintah untuk dirambah atau dimanfaatkan untuk perladangan. Selain alasan keterbatasan, penanaman cash crops, terutama kopi atau coklat lebih menguntungkan karena amat membantu penduduk lokal meningkatkan kesejahteraan- 
KEARIFAN BUDAYA MASYARAKAT TRADISIONAL DALAM PENGELOLAAN LINGKUNGAN HIDUP

nya. Akibat dikenalnya komoditas perladangan tersebut, dalam komunitas peladang pada umumnya terdapat, paling tidak dua cara bercocok tanam, yakni berladang dan berkebun. Dan perubahan pola perladangan ini, tidak saja berdampak pada sistem ekonomi pedesaan, tetapi juga terhadap sistem ekologi yang memungkinkan sumberdaya hutan dimanfaatkan secara berkelanjutan.

Memahami praktek perladangan dan mencermati timbulnya perubahan pola perladangan, sebenarnya tidak perlu meresahkan pemerintah. Dalam hal ini penulis sependapat dengan Emil Salim yang menyatakan, bahwa para peladang berpindah seyogyanya tidak perlu menjadi obyek penerbitan, tetapi sebagai subyek pembangunan, perlu dibawa serta dalam proses pembangunan yang lebih maju.

Mengintegrasikan penduduk dalam dan sekitar hutan dalam pembangunan akan berarti memberikan tanggungjawab secara lebih besar kepada mereka untuk menjaga keseimbangan ekosistem hutan. Namun perlu dicatat, komitmen pemerintah, dalam hal ini instansi-instansi yang tekait dalam berbagai pihak yang berkepentingan dengan hutan dalam upaya meningkatkan kesejahteraan penduduk lokal hams dibuktikan. Pada saat ini, pada umumnya desa-desa hutan adalah desa-desa tertinggal, bukan saja dalam bentuk ekonomi, tetai hampir dalam semua aspek kehidupan. Ironisnya, mengapa hal ini terjadi pada penduduk dalam dan sekitar hutan yang notabene hidup dalam suatu kawasan yang memiliki potensi ekonomi yang demikian besar.

\section{BENTUK KEARIFAN BUDAYA ORANG TUBBI}

Hutan primer maupun hutan sekunder yang menyimpan kekayaan jenis vegetasi, khususnya pohon-pohonan, dipandang oleh penduduk sebagai suatu komunitas yang memiliki sukma yang peranannya demikian besar bagi kehidupan manusia. Karena itu manusia tidak boleh memperlakukan hutan sebagai obyek semata-mata untuk kepentingan diri sendiri, tetapi komunitas hutan harus dipandang sebagai subyek yang ikut memberikan spirit dan manfaat bagi penduduk sekitarnya.

Entitas-entitas penghuni hutan dalam bentuk roh-roh halus dianggap oleh penduduk sebagai penjaga hutan yang memungkinkan suatu hutan tetap lestari dan menjaga agar ekosistem hutan tidak terganggu. Karena itu hutan primer maupun hutan sekunder yang ditumbuhi pohon-pohon besar, tumbuhtumbuhan perdu, tumbuh-tumbuhan terna, maupun epifit dan liana dipandang sebagai komunitas yang misterius dan menyeramkan. Namun demikian, bukan berarti hutan tidak boleh dijamah atau dirambah untuk kepentingan penduduk sekitarnya.

Perambahan hutan telah dilakukan oleh penduduk Tubbi Tutallu sejak dahulu kala dalam bentuk perladangan berpindah, pengambilan hasil hutan, seperti rotan, ijuk, kayu pohon, bambu, pakan ternak dan sebagainya. Hanya saja, dalam kegiatan perambahan tersebut, penduduk memiliki semacam aturan, katakanlah kebijakan lingkungan yang memungkinkan keseimbangan lingkungan tersebut tidak begitu terganggu. Ketaatan penduduk terhadap konsepsi ini, tercermin pada waktu penduduk membuka lahan perladangan, dengan melibatkan sandro pare (sobboq) untuk memohon izin terlebih dahulu kepada penjaga hutan yang dahulu diyakini sebagai Dewata Agung. Sandro Pare yang memiliki kemampuan supernatural menjadi perantara, menjamin terjaganya keseimbangan ekosistem, dalam artian bahwa suatu perladangan yang telah digarap sekian tahun untuk kemudian ditinggalkan, dijamin menjadi hutan kembali seperti sedia kala.

Penduduk memahami betul, bahwa hutan adalah sumber kehidupan dan karenanya harus diperlakukan secara bijaksana. 


\section{KEARIFAN BUDAYA MASYARAKAT TRADISIONAL DALAM PENGELOLAAN LINGKUNGAN HIDUP}

Penduduk tidak pernah melakukan penebangan secara brutal, tetapi hanya menebang pohon yang betul-betul mereka perkirakan cukup usia sehingga dapat dimanfatkan secara optimal. Kayu pohon yang telah tua akan lebih tahan lama dan tidak muda dimakan rayap dan faktor kesulitan untuk mengambil kayu relatif rendah. Misalnya pohon kayu, walaupun dianggap memenuhi syarat, tetapi terletak pada kemiringan tinggi tidak akan menjadi pilihan utama. Penduduk mengetahui bahwa pohon tersebut berfungsi sebagai penyangga humus tanah.

Penduduk juga akan memperlakukan jenis tumbuhan lainnya seperti bambu. Hanya bambu yang benar-benar tua yang mereka tebang, walaupun terletak di tengahtengah rumpun. Untuk mengatasi kesulitan tersebut, penduduk biasanya terlebih dahulu memanjat ke atas dan menebas rantingranting bambu di sebelah atas, baru kemudian ranting bambu sebelah bawah, sebelum menebangnya, sehingga bambu yang telah ditebang relatif lebih muda untuk menariknya ke luar rumpun.

Kebijakan lingkungan juga tercermin dalam hal perambahan rotan. Walaupun nilai ekonomi rotan cukup tinggi, tetapi penduduk kawasan hutan mengambil rotan tanpa mengganggu vegetasi pohon tempat rotan melilit. Pohon tidak boleh ditebang hanya karena rotan, tetapi diupayakan mengambil rotannya saja. Juga rotan yang ujungnya tidak tSrlihat tidak boleh diambil karena ada kemungKinan rotan tersebut masih muda.

Kebiasaan membuka lahan pada tanah kemiringan menyebabkan penduduk memiliki cara-cara tertentu memperlakukan tanah kemiringan dengan teknik yang oleh penduduk setempat disebut "balete". Balete dapat disebut sebagai cara pembuatan terasering tradisional pada tanah miring, yang akan dipersiapkan sebagai lahan perladangan. Cara penduduk membuat terasering tradisional adalah (1) Menyususn batu-batu gunung yang berfungsi sebagai penahan humus tanah, (2) Batu-batu tersebut dilapisi dengan rumput-rumput, (3) Jarak antar satu baris batu penahan dengan lainnya disesuaikan dengan faktor kemiringan lahan.

Hanya saja model terasering tradisional tersebut mudah rusak karena tidak ditanami tanaman penahan, seperti pohon lamtoro yang sudah tumbuh di daerah ini sejak dahulu. Penduduk biasa menyebutnya ayu ranni (Leucena glauca).

Kearifan budaya disini dimaksudkan sebagai akumulasi pengetahuan lokal (indegenous knowledge) dalam seperangkat pengetahuan penduduk mengenai dunia komunitasnya didasarkan pada referensi kosmologis dan kebudayaan setempat. Dengan demikian, kearifan penduduk dalam pengelohan lingkungan tidak lain adalah bentuk pengetahuan lokal bersumber pada pengamalan penduduk beradaptasi dengan lingkungannya secara turun temurun. Karena pengetahuan tersebut telah mengendap demikian lama, menyebabkan pengetahuan lokal tersebut menjadi pedoman dalam mengelola dan memanfaatkan sumberdaya alam secara lebih bijaksana.

\section{PENUTUP}

Keresahan pemerintah terhadap aktivitas perladangan berpindah yang dilakukan oleh masyarakat yang relatif masih tradisional, sebenarnya tidak perlu terjadi. Hal ini disebabkan praktek perladangan yang mereka lakukan ternyata didasarkan pada pertimbangan-pertimbangan rasional, bersumber pada kearifan lingkungan yang mereka pahami secara turun menurun. Apa yang perlu dilakukan adalah upaya "memberdaydkan" kelompok masyarakat tersebut agar mereka dapat keluar dari belitan kemiskinan struktural yang selama ini dialami umumnya penduduk dalam dan sekitar hutan. Perhutanan sosial merupakan salah satu tersebut mengkombinasikan aspek sosial, ekonomi dan budaya komunitas penduduk dalam dan 
sekitar hutan. Lagi pula, perhutanan sosial merupakan wahana untuk mendidik penduduk untuk bertanggung jawab bagi kelestarian hutan. Dengan demikian, dari dimensi ekologis, upaya perhutanan sosial perlu didukung.

Persoalan mendasar yang perlu dipikirkan adalah, bagaimana pemerintah daerah dan instansi terkait mewujudkan program perhutanan sosial yang benar-benar lahir dari sebuah komitmen untuk memberdayakan masyarakat tradisional di dalam dan sekitar hutan. Terus terang, mereka bukan sebuah komunitas yang selalu menjadi obyek penerbitan dan menjadi obyek tudingan untuk selalu dipersalahkan, tetapi mereka, sebenarnya memiliki potensi untuk didukung dan dikembangkan.

\section{DAFTAR KEPUSTAKAAN}

Dove, Michel R, Theories of Swidden agri1983 culture and the political Ekonomi of Ignorance, Agroforest System No. 1.

Netting, Robert McC

$$
\begin{aligned}
& \text { Cultural Ecology, Benya- } \\
& \text { min/Cumming Publishing } \\
& \text { Co, California. }
\end{aligned}
$$

Sani M. Yamin 1984

Model ekosistem Konteks-
tual Untuk Pemahaman
Karakteristik Sosial budaya
Perambah hutan di Kali-
mantan dan Sulawesi

Kasus penduduk dalam kawasan dan sekitar Hutan di desa Tubbi - Polmas, Dewan Riset Nasiorial LIPI, Jakarta.

Vayda, Andrew P. 1981

Research ini East Kalimantan on Interactions between People and forest : A Preliminary report, dalam Borneo Research Bulletin. 